\title{
Integration of Press-Hardening Technology into Processing of Advanced High Strength Steels JIRKOVÁ Hana ${ }^{1, a^{*}}$, OPATOVÁ Kateřina ${ }^{1, b}$, KÁŇA Josef $^{1, c}$, BUBLÍKOVÁ Dagmar ${ }^{1, \mathrm{~d}}$ and BYSTRIANSKÝ Martin ${ }^{1, \mathrm{e}}$
}

\author{
${ }^{1}$ University of West Bohemia, RTI - Regional Technological Institute, Univerzitní 22, \\ Pilsen, 306 14, Czech Republic \\ ahstankov@rti.zcu.cz, bopatovak@rti.zcu.cz, 'jkana@rti.zcu.cz, 'natasha@rti.zcu.cz, \\ embyst@rti.zcu.cz
}

\section{Keywords: High Strength Steel, Press-hardening, TRIP Steel, Q\&P Process}

\begin{abstract}
Development of high strength or even ultra-high strength steels is mainly driven by the automotive industry which strives to reduce the weight of individual parts, fuel consumption, and $\mathrm{CO}_{2}$ emissions. Another important factor is the passenger safety which will improve by the use of these materials. In order to achieve the required mechanical properties, it is necessary to use suitable heat treatment in addition to an appropriate alloying strategy. The main problem of these treatments is the isothermal holding time. These holding times are technologically demanding which is why industry seeks new possibilities to integrate new processing methods directly into the production process. One option for making high-strength sheet metals is press-hardening which delivers high dimensional accuracy and a small spring-back effect. In order to test the use of AHSS steels for this technology, a material-technological modelling was chosen. Material-technological models based on data obtained directly from a real press-hardening process were examined on two experimental steels, CMnSi TRIP and 42SiCr. Variants with isothermal holding and continuous cooling profiles were tested. It was found that by integrating the Q\&P process (quenching and partitioning) into press hardening, the 42SiCr steel can develop strengths of over $1800 \mathrm{MPa}$ with a total elongation of about $10 \%$. The CMnSi TRIP steel with lower carbon content and without chromium achieved a tensile strength of $1160 \mathrm{MPa}$ with a total elongation of $10 \%$.
\end{abstract}

\section{Introduction}

High-strength steels are promising materials for applications in the automotive industry. As they typically contain a multiphase microstructure and exhibit numerous strengthening mechanisms, they can attain a wide range of mechanical properties [1,2]. Chemical composition is another of their advantages, being very cost effective and comprising relatively few alloying elements. Their mechanical properties are obtained, for the most part, by means of appropriate heat treatment or thermomechanical processing sequences.

With their good combination of strength and ductility, TRIP steels fall into this group as well [35]. They are treated using intercritical annealing which involves isothermal holding in the bainitic transformation region. At this stage, bainite forms and retained austenite becomes stable. Stability of retained austenite (RA) is governed by the carbon content and by the RA morphology and distribution [6]. Higher strength levels are obtained in martensitic steels by Q\&P processing. It comprises isothermal holding between the $\mathrm{M}_{\mathrm{s}}$ and $\mathrm{M}_{\mathrm{f}}$ temperatures; and leads to a mixture of martensite and foil-like retained austenite between martensite needles [7]. Strengths of more than $2000 \mathrm{MPa}$ combined with up to $10 \%$ elongation are obtained.

Given their favourable properties and ability to absorb crash energy, these materials could be used for making body-in-white safety components. One of the processes by which such highstrength components can be manufactured is press-hardening. It enables sheets of hardenable materials to be worked using lower forming forces and to have the springback effect reduced [8,9]. Therefore, processing of these steels without isothermal holding needs to be tested or post-forming heat treatment must be added. 


\section{Experimental Programme}

For this experiment, several heat treatment routes were proposed. They were based on presshardening and applied to two experimental steels. One of them was CMnSi TRIP steel, a typical TRIP steel, and the other was $42 \mathrm{SiCr}$, one of the steels for Q\&P processing. The proposed sequences reflected press hardening in a tool at RT and heat treatment. The purpose was to determine and describe, firstly, the effect of varying heat treatment parameters on microstructure and mechanical properties and, secondly, the suitability of these steels for press-hardening.

Experimental Materials. CMnSi TRIP is a low-alloy steel with $0.2 \%$ carbon, whose only alloying elements are manganese and silicon (Table 1). This chemistry was chosen for stability of retained austenite, solid solution strengthening, and to prevent carbide precipitation during bainite formation [4]. Specimens for heat treatment were made by waterjet cutting from a soft-annealed sheet of $1.5 \mathrm{~mm}$ thickness. Its microstructure consisted of ferrite and pearlite; the hardness was $180 \mathrm{HV} 10$. Characteristics of phase transformations were calculated using the JMatPro software (Release 9.0, Sente Software Ltd., 2016). The $\mathrm{M}_{\mathrm{s}}$ temperature was found to be $370^{\circ} \mathrm{C}$ and the $\mathrm{M}_{\mathrm{f}}$ was $257^{\circ} \mathrm{C}$.

42 $\mathrm{SiCr}$ had a higher carbon content than $\mathrm{CMnSi}$ : $0.43 \%$. It also contained chromium which greatly strengthens solid solution and improves hardenability (Table 1). The initial microstructure of the sheet of this steel consisted of pearlite and a small amount of ferrite. Its hardness was $290 \mathrm{HV} 10$. Owing to the higher carbon level, the $\mathrm{M}_{\mathrm{s}}$ was $290^{\circ} \mathrm{C}$ and the $\mathrm{M}_{\mathrm{f}}$ temperature was $178^{\circ} \mathrm{C}$.

Table 1. Chemical compositions of experimental steels [wt. \%]

\begin{tabular}{|c|c|c|c|c|c|c|c|c|c|c|}
\hline Steel & $\mathrm{C}$ & $\mathrm{Mn}$ & $\mathrm{Si}$ & $\mathrm{Al}$ & $\mathrm{Nb}$ & $\mathrm{P}$ & $\mathrm{S}$ & $\mathrm{Ni}$ & $\mathrm{M}_{\mathrm{s}}$ & $\mathrm{M}_{\mathrm{f}}$ \\
\hline $\mathrm{CMnSi}$ & 0.21 & 1.4 & 1.8 & 0.006 & 0.002 & 0.007 & 0.005 & 0.07 & 370 & 257 \\
\hline $42 \mathrm{SiCr}$ & 0.43 & 0.68 & 1.96 & 0.008 & 0.07 & 0.01 & 0.01 & 0.07 & 298 & 178 \\
\hline
\end{tabular}

Material-technological modelling of press-hardening process. In order to be able to test press-hardening on these newly-developed high-strength steels, material-technological modelling was employed. Using this technique, thermal and deformation routes which were measured in a real-world forming process can be tested on a chosen material. It is performed in a thermomechanical simulator which uses high-frequency electric resistance heating and offers high heating and cooling rates (up to $200^{\circ} \mathrm{C} / \mathrm{s}$ ). The data for developing the model was measured in a realworld process, with the tool either at room temperature or pre-heated to various temperatures. It allowed various cooling profiles to be designed to match the materials'

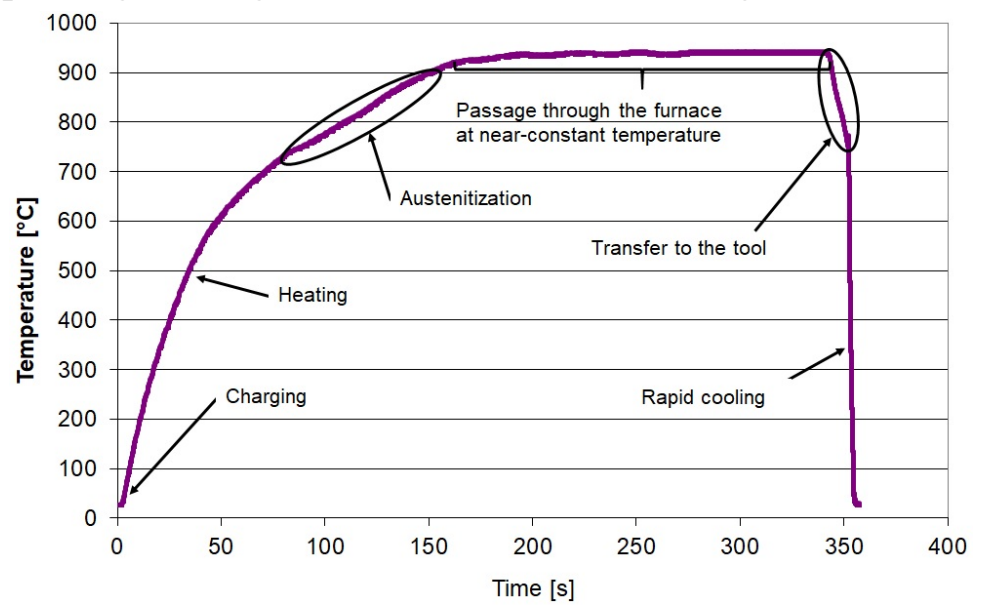

Fig. 1. Material-technological model of the presshardening process for a thermomechanical simulator, tool at room temperature (RT) characteristics.

In the first sequence proposed, the tool was at room temperature (Fig. 1). The initial heating to $937^{\circ} \mathrm{C}$ was followed by soaking for 100 seconds. Then, a 7-second step represented air cooling of the workpiece during transfer to the forming tool. The temperature dropped to $760^{\circ} \mathrm{C}$. The next step was a simulation of press-hardening in a tool at room temperature at a cooling rate of $100^{\circ} \mathrm{C} / \mathrm{s}$ (the $\mathrm{CMnSi}-01$ sequence). In other sequences, the impact of cooling rate was tested. The cooling rate was reduced to $12^{\circ} \mathrm{C} / \mathrm{s}$ and $6^{\circ} \mathrm{C} / \mathrm{s}(\mathrm{CMnSi}-02$ and $\mathrm{CMnSi}-03$ sequences, respectively). TRIP steels 
are intercritically annealed to obtain a mixture of ferrite, bainite and retained austenite. Therefore, isothermal holding was incorporated into cooling in some sequences. In the first one of these, cooling rate changed at $425^{\circ} \mathrm{C}$ from $51^{\circ} \mathrm{C} / \mathrm{s}$ to $1.5^{\circ} \mathrm{C} / \mathrm{s}$ (the $\mathrm{CMnSi}-04$ sequence). Then, sequences with isothermal holding at a bainitic transformation temperature for 600 seconds and 900 seconds were used (the CMnSi-05 and 06 sequences, respectively). The purpose of the last sequence was to study the effect of the rate of cooling after isothermal holding at $425^{\circ} \mathrm{C}$ (the $\mathrm{CMnSi}-07$ sequence).

Table 2. Heat treatment and mechanical properties of the CMnSi TRIP steel

\begin{tabular}{|c|c|c|c|c|c|c|c|c|c|}
\hline Treatment & $\begin{array}{l}\text { Tool } \\
\text { temp. } \\
{\left[{ }^{\circ} \mathrm{C}\right]}\end{array}$ & $\begin{array}{l}\text { Holding } \\
\text { time }[\mathrm{s}]\end{array}$ & $\begin{array}{l}\text { Cooling } \\
\text { rate to the } \\
\text { tool }\left[{ }^{\circ} \mathrm{C} / \mathrm{s}\right]\end{array}$ & $\begin{array}{l}\text { Cooling rate } \\
\text { from the tool } \\
\qquad\left[{ }^{\circ} \mathrm{C} / \mathrm{s}\right]\end{array}$ & $\begin{array}{c}\text { HV10 } \\
{[-]}\end{array}$ & $\begin{array}{c}\text { Offset } \\
\text { YS } \\
\left(\mathrm{R}_{\mathrm{p} 0.2}\right) \\
{[\mathrm{MPa}]}\end{array}$ & $\begin{array}{c}\text { UTS } \\
\left(\mathrm{R}_{\mathrm{m}}\right) \\
{[\mathrm{MPa}]}\end{array}$ & $\begin{array}{l}\mathrm{A}_{20} \\
{[\%]}\end{array}$ & $\begin{array}{l}\text { RA } \\
{[\%]}\end{array}$ \\
\hline CMnSi-01 & \multirow{3}{*}{ RT } & - & 100 & - & 241 & 410 & 876 & 17 & 3 \\
\hline CMnSi-02 & & - & 12 & - & 225 & 396 & 740 & 19 & \\
\hline CMnSi-03 & & - & 6 & - & 235 & 430 & 787 & 22 & \\
\hline CMnSi-04 & \multirow{4}{*}{425} & - & 51 & 1.5 & 250 & 374 & 844 & 21 & 4 \\
\hline CMnSi-05 & & 600 & 51 & 1.5 & 402 & 676 & 1160 & 10 & 11 \\
\hline CMnSi-06 & & 900 & 51 & 1.5 & 206 & 316 & 758 & 20 & 6 \\
\hline CMnSi-07 & & 600 & 51 & 0.7 & 213 & 328 & 744 & 19 & 7 \\
\hline
\end{tabular}

Table 3. Heat treatment and mechanical properties of $42 \mathrm{SiCr}$ steel

\begin{tabular}{|l|c|c|c|c|c|c|c|c|}
\hline Treatment & $\begin{array}{c}\text { Tool temperature } \\
{\left[{ }^{\circ} \mathrm{C}\right]}\end{array}$ & $\begin{array}{c}\text { Cooling } \\
\text { rate }\left[{ }^{\circ} \mathrm{C} / \mathrm{s}\right]\end{array}$ & $\mathrm{PT} / \mathrm{Pt}\left[{ }^{\circ} \mathrm{C} / \mathrm{s}\right]$ & $\begin{array}{c}\mathrm{HV} 10 \\
{[-]}\end{array}$ & $\begin{array}{c}\text { Offset } \\
\text { yield } \\
\text { strength } \\
\left(\mathrm{R}_{\mathrm{p} 0.2)}\right. \\
{[\mathrm{MPa}]}\end{array}$ & $\begin{array}{c}\text { UTS } \\
\left(\mathrm{R}_{\mathrm{m}}\right) \\
{[\mathrm{MPa}]}\end{array}$ & $\begin{array}{c}\mathrm{A}_{20} \\
{[\%]}\end{array}$ & $\begin{array}{c}\mathrm{RA} \\
{[\%]}\end{array}$ \\
\hline 42SiCr-01 & $\mathrm{RT}$ & 100 & - & 653 & 1420 & 1906 & 1 & 4 \\
\hline $42 \mathrm{SiCr}-02$ & 200 & 100 & $\begin{array}{c}\text { air cooling } \\
\text { from } 200^{\circ} \mathrm{C}\end{array}$ & 614 & 1462 & 2057 & 5 & \\
\hline 42SiCr-03 & 200 & 100 & $250 / 600$ & 575 & 1130 & 1850 & 10 & 14 \\
\hline 42SiCr-04 & 200 & 50 & $250 / 600$ & 545 & 1248 & 1802 & 9 & 11 \\
\hline 42SiCr-05 & 200 & 10 & $250 / 600$ & 482 & 935 & 1642 & 4 & \\
\hline 42SiCr-06 & 200 & 100 & $250 / 800$ & 569 & 1420 & 1798 & 8 & \\
\hline 42SiCr-07 & 200 & 100 & $250 / 400$ & 573 & 1472 & 1844 & 9 & \\
\hline 42SiCr-08 & 200 & 100 & $230 / 600$ & 600 & 1488 & 1919 & 8 & \\
\hline 42SiCr-09 & 200 & 100 & $270 / 600$ & 565 & 1337 & 1722 & 7 & \\
\hline
\end{tabular}

The first sequence applied to $42 \mathrm{SiCr}$ steel represented cooling of sheet metal in a tool at room temperature (the 42SiCr-01 sequence) (Table 3). Other sequences simulated the typical processing of this steel, the Q\&P process. In the second sequence, the cooling rate changed below $200^{\circ} \mathrm{C}$ (the 42SiCr-02 sequence). In the next sequence, cooling stopped at $200^{\circ} \mathrm{C}$ and was followed by reheating to a partitioning temperature of $250^{\circ} \mathrm{C}$ and holding for 600 seconds (the $42 \mathrm{SiCr}-03$ sequence), while the cooling rate prior to placement in the tool was kept at $100^{\circ} \mathrm{C} / \mathrm{s}$. Lower cooling rates of $50^{\circ} \mathrm{C} / \mathrm{s}$ and $10^{\circ} \mathrm{C} / \mathrm{s}$ were tested as well (42SiCr-04 and 05). The time at the partitioning temperature plays a role in the stability of retained austenite. For this reason, sequences with holding times of $800 \mathrm{~s}$ and $400 \mathrm{~s}$ were used (42SiCr-06 and 07). The last sequences introduced change partitioning temperatures: $230^{\circ} \mathrm{C}$ and $270^{\circ} \mathrm{C}(42 \mathrm{SiCr}-08$ a 09$)$.

Methods of evaluation. Microstructures were examined by optical (OM) and scanning electron microscopy (SEM). Tescan VEGA 3 and Zeiss EVO MA 25 scanning electron microscopes were employed. The amount of retained austenite was measured by X-ray diffraction. The automatic powder diffractometer AXS Bruker D8 Discover with a HI-STAR position-sensitive area detector 
and a cobalt X-ray source $(\lambda \mathrm{K} \alpha=0.1790307 \mathrm{~nm})$ was employed for this measurement. Measurements were taken in the centres of metallographic sections at diffraction angles in the interval of $25 \div 110^{\circ} 2 \vartheta$. Mechanical properties were measured by HV10 hardness testing and tensile testing.

\section{Results and Discussion}

The sequence which represented press-hardening in a tool at RT at a cooling rate of $100^{\circ} \mathrm{C} / \mathrm{s}$ caused the CMnSi TRIP steel to develop a ferritic microstructure with martensite and $3 \%$ of retained austenite (Fig. 2). The hardness was $241 \mathrm{HV} 10$. The ultimate strength was $876 \mathrm{MPa}$ and elongation reached $17 \%$ (Table 2). After the cooling rate had been decreased from $100^{\circ} \mathrm{C} / \mathrm{s}$ to $6{ }^{\circ} \mathrm{C} / \mathrm{s}$, neither substantial differences in microstructure nor pearlite formation were detected (Fig. 3). The ultimate strength decreased by $100 \mathrm{MPa}$ and the elongation level was $22 \%$.

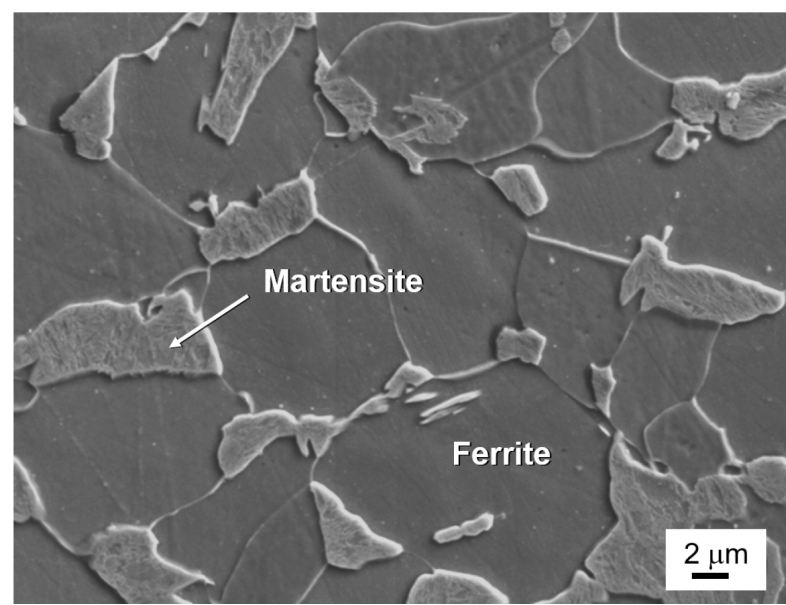

Fig. 2. CMnSi-02 schedule - press-hardening at a rate of $100^{\circ} \mathrm{C} / \mathrm{s}$ in a tool at $\mathrm{RT}$, ferriticmartensitic microstructure, SEM

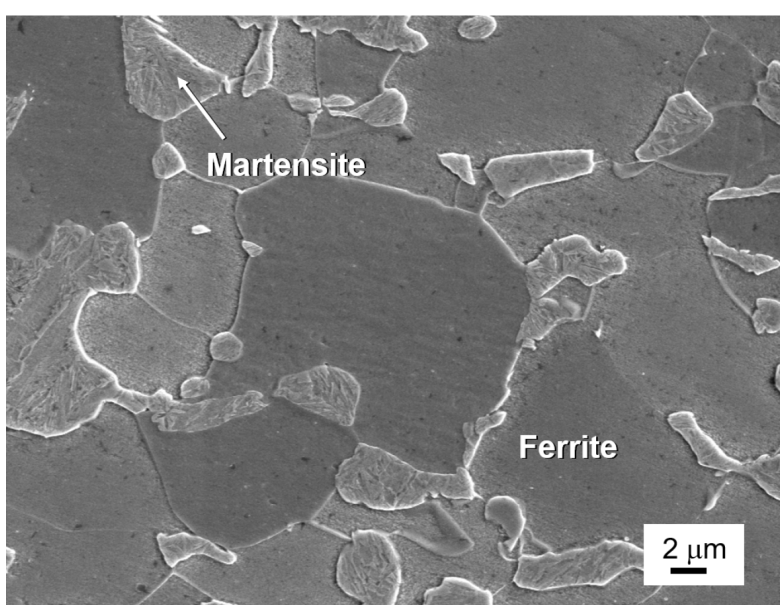

Fig. 3. CMnSi-03 schedule - press-hardening at a rate of $6^{\circ} \mathrm{C} / \mathrm{s}$ in a tool at $\mathrm{RT}$, ferriticmartensitic microstructure, SEM

The sequence which comprised holding at $425^{\circ} \mathrm{C}$ for $600 \mathrm{~s}$ promoted formation of bainite. The resulting microstructure was a mixture of martensite, bainite and a small amount of free ferrite (Fig. 4). The isothermal hold contributed to stability of retained austenite (RA). The amount of RA was $11 \%$. The reduced volume of ferrite and the increase in the amount of hardening microstructure were reflected in a notable increase in UTS to $1160 \mathrm{MPa}$ and in reduced elongation: $10 \%$. Neither an extended holding time of 900 seconds, nor a reduced cooling rate after isothermal holding have further stabilised retained austenite whose amount therefore decreased to $6 \%$ and $7 \%$, respectively. In both these schedules, the resulting ultimate strength was in the $744-758 \mathrm{MPa}$ interval. The elongation levels were about $20 \%$.

After the 42SiCr steel, which had a higher carbon level and contained chromium, was processed according to the first schedule which represented press-hardening in a tool at RT, its microstructure consisted of a majority of martensite and a small amount of bainite. The volume fraction of retained austenite was a mere 4\%. Hardness was $653 \mathrm{HV} 10$. The ultimate strength was $1906 \mathrm{MPa}$ and elongation reached 1\%. Elongation did not increase even after the rate of cooling below $200^{\circ} \mathrm{C}$ had been reduced in the 02 sequence. Improved elongation was obtained by incorporating the Q\&P process into cooling. Elongation increased to $10 \%$ and high ultimate strength remained: $1850 \mathrm{MPa}$. As in previous cases, the microstructure was martensitic and contained a small amount of bainite. However, the fraction of retained austenite increased to $14 \%$ (Fig. 5).

After the cooling above $200^{\circ} \mathrm{C}$ had been slowed down from $100^{\circ} \mathrm{C}$ to $50^{\circ} \mathrm{C} / \mathrm{s}$, a small amount of free ferrite formed (Fig. 6). As a consequence, hardness decreased slightly from 575 HV 10 to $545 \mathrm{HV} 10$, as did the ultimate strength whose value was $1802 \mathrm{MPa}$. Elongation was 9\%. Yet another reduction in the cooling rate to $10^{\circ} \mathrm{C} / \mathrm{s}$ led to an increased proportion of ferrite, to even lower mechanical properties, and to no increase in elongation (Fig. 7). 
Extended holding time at the partitioning temperature, from $600 \mathrm{~s}$ to $800 \mathrm{~s}$, resulted in reduced ultimate strength of $1798 \mathrm{MPa}$ and elongation of $8 \%$. Reducing the partitioning temperature from $250^{\circ} \mathrm{C}$ to $230^{\circ} \mathrm{C}$ caused the ultimate strength to increase from $1850 \mathrm{MPa}$ to $1919 \mathrm{MPa}$, whereas elongation slightly decreased to $8 \%$. By contrast, increasing the partitioning temperature to $270^{\circ} \mathrm{C}$ has led to a lower ultimate strength, $1722 \mathrm{MPa}$, and no change in elongation. In this case, the microstructure was very similar to the others. It consisted of martensite with a small amount of bainite, no free ferrite and no visible precipitates.

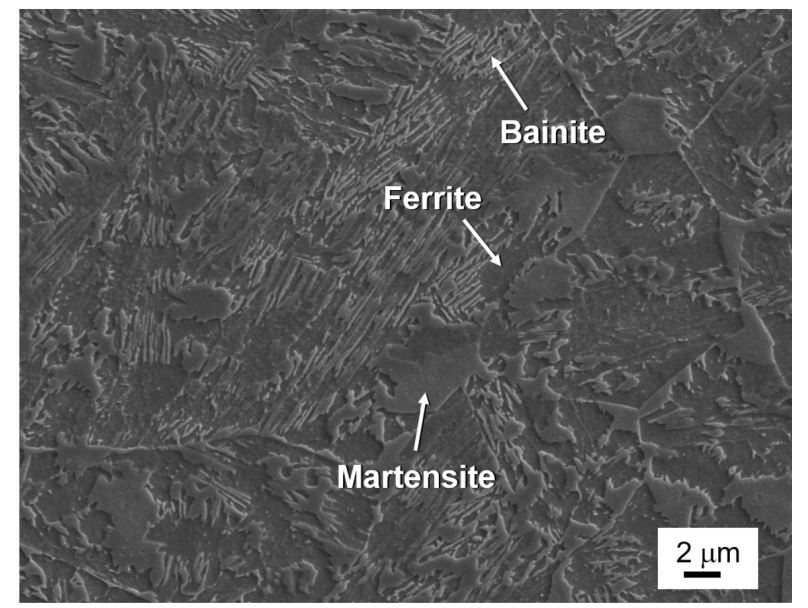

Fig. 4. Sequence $\mathrm{CMnSi}-05$ - holding at $425^{\circ} \mathrm{C}$ for $600 \mathrm{~s}$, martensitic-bainitic structure with ferrite and retained austenite, SEM

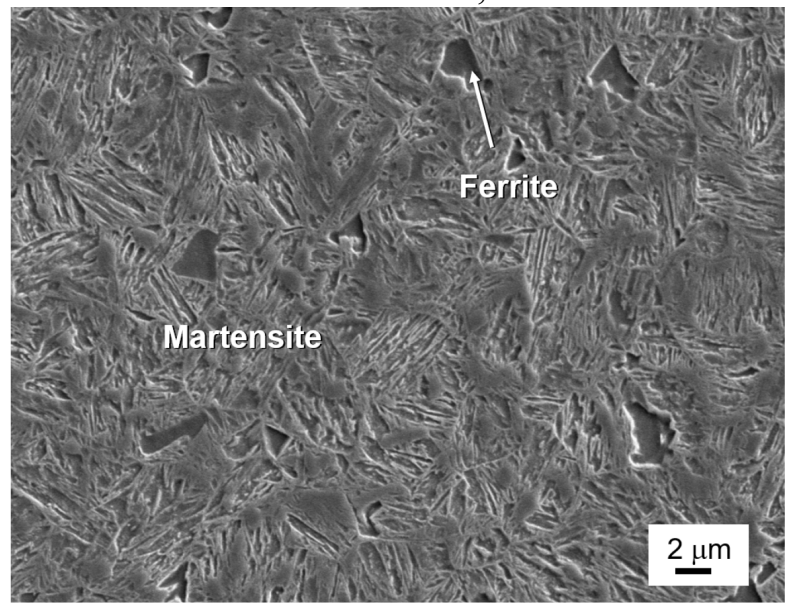

Fig. 6. Sequence 42SiCr-04 - press-hardening with Q\&P processing $-50^{\circ} \mathrm{C} / \mathrm{s}-200^{\circ} \mathrm{C}-$ $250^{\circ} \mathrm{C} / 600 \mathrm{~s}$, martensite with small amounts of bainite and ferrite, SEM

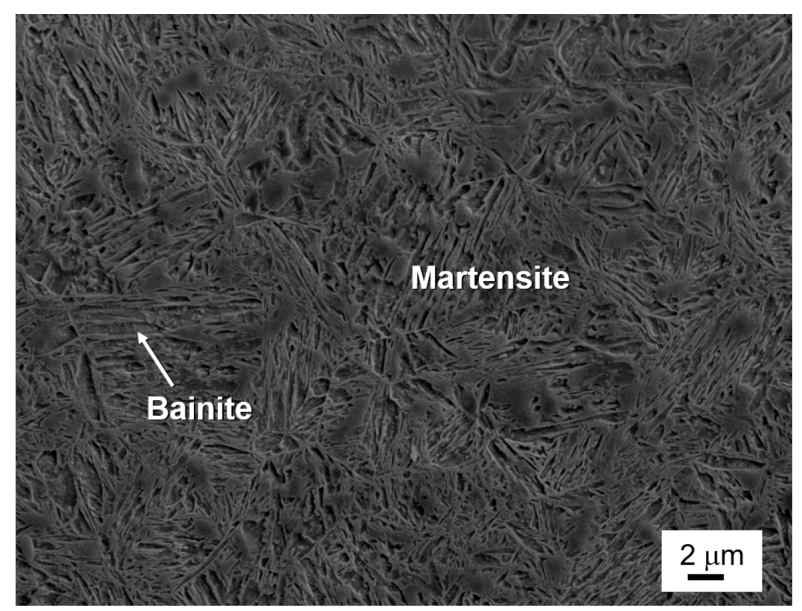

Fig. 5. Sequence 42SiCr-03 - press hardening with Q\&P processing $-200^{\circ} \mathrm{C}-250^{\circ} \mathrm{C} / 600 \mathrm{~s}$, martensite with a small amount of bainite, SEM

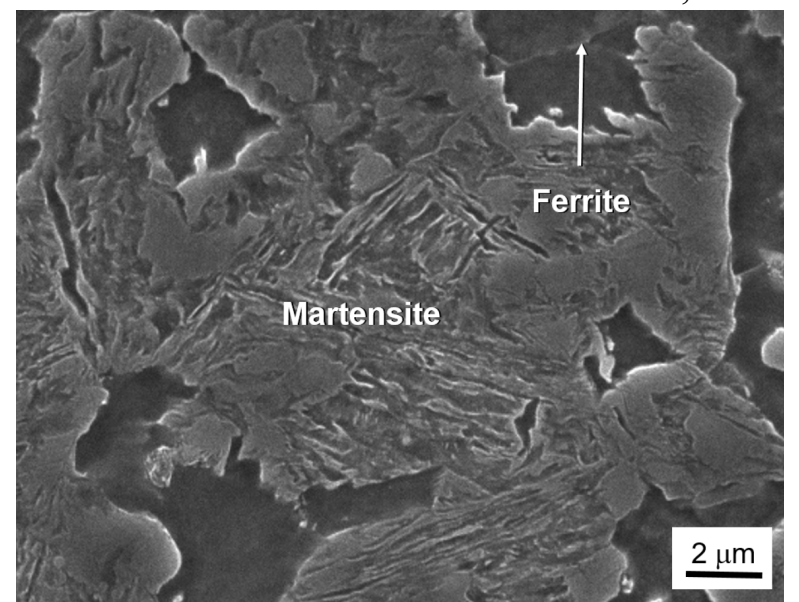

Fig. 7. Sequence $42 \mathrm{SiCr}-05$ - press-hardening with Q\&P processing $-10^{\circ} \mathrm{C} / \mathrm{s}-200^{\circ} \mathrm{C}-$ $250^{\circ} \mathrm{C} / 600 \mathrm{~s}$, martensite with ferrite and a small amount of bainite, SEM

\section{Summary}

In this experiment, a press-hardening route was tested which had been designed on the basis of data from a real-world forming process. It was applied to two high-strength steels: CMnSi TRIP and $42 \mathrm{SiCr}$.

It was found that in order to obtain the desired mixed microstructure of martensite, bainite, ferrite and retained austenite in the CMnSi TRIP steel, press-hardening must be followed by isothermal annealing at $425^{\circ} \mathrm{C}$. By this means, strengths of more than $1100 \mathrm{MPa}$ combined with up to $10 \%$ elongation can be obtained.

The incorporation of the Q\&P process into the cooling process of the $42 \mathrm{SiCr}$ steel, which had a higher level of carbon and chromium, was tested successfully. As a result, it became possible to increase elongation to $10 \%$ while the ultimate strength was $1850 \mathrm{MPa}$. 


\section{Acknowledgement}

The present contribution has been prepared under project LO1502 "Development of the Regional Technological Institute" under the auspices of the National Sustainability Programme I of the Ministry of Education of the Czech Republic aimed to support research, experimental development and innovation.

\section{References}

[1] J. Zhao, Z. Jiang, Thermomechanical processing of advanced high strength steels, Progress in Materials Science. 94 (2018) 174-242.

[2] H. Aydina, E. Essadiqi, I. Jung, S. Yue, Development of 3rd generation AHSS with medium Mn content alloying compositions, Materials Science and Engineering: A. 564 (2013) 501-508.

[3] I.B. Timokhina, P.D. Hodgson, E.V. Pereloma, Effect of microstructure on the stability of retained austenite in transformation-induced-plasticity steels, Metall Mat Trans A: Phys Metall Mat Sci. 35A (2004) 2331-41.

[4] W. Bleck, Using the TRIP efekt - the down of a promising group of cold formable steels, in: B.C. De Cooman (Eds.), Proceedings of the International Conference on TRIP - Aided High Strength Ferrous Alloys, GRIPS' SPARKLING WORLD OF STEEL, Aachen, 2002, pp. 13-24.

[5] Ch.G. Lee, S.J. Kim, T.H. Lee, S.Lee, Effects of volume fraction and stability of retained austenite on formability in a $0,1 \mathrm{C}-1,5 \mathrm{Si}-1,5 \mathrm{Mn}-0,5 \mathrm{Cu}$ TRIP-aided cold-rolled steel sheet, Materials Science and Engineering A. 371 (2003) 16-23.

[6] B.C. De Cooman, Structure-properties relationship in TRIP steels containing carbide-free bainite, Current opinion in Solid State and Materials Science. 8 (2004) 285-303.

[7] D.V. Edmonds et al, Quenching and partitioning martensite - A novel steel heat treatment. Materials Science and Engineering A. 438-440 (2006) 25-34.

[8] E.A. Ariza, Characterization and methodology for calculating the mechanical properties of a TRIP-steel submitted to hot stamping and quenching and partitioning (Q\&P), Materials Science and Engineering A. 671 (2016), 54-59.

[9] H. Karbasian, A.E. Tekkaya, A review on hot stamping, Journal of Materials Processing Technology. 210 (2010), 2103-2118.

[10]B. Mašek, H. Jirková, L. Kučerová, M. Zemko, Improvement of Mechanical Properties of automotive Components Using Hot Stamping with Integrated Q-P Process, Journal of Iron and Steel Research International. 18 (2011) 730-734.

[11] B. Mašek et al, Transformation-Induced Plasticity in Steel for Hot Stamping, Materiali in Technologije. 48 (2014) 555-557.

[12] L. Kučerová, H. Jirková, B. Mašek, Continuous Cooling of CMnSi TRIP Steel, Materialstoday: Proceedings. 2 (2015), S677-S680. 